\title{
The legacy of Circle women's engagement with the Bible: Reflections from an African male biblical scholar
}

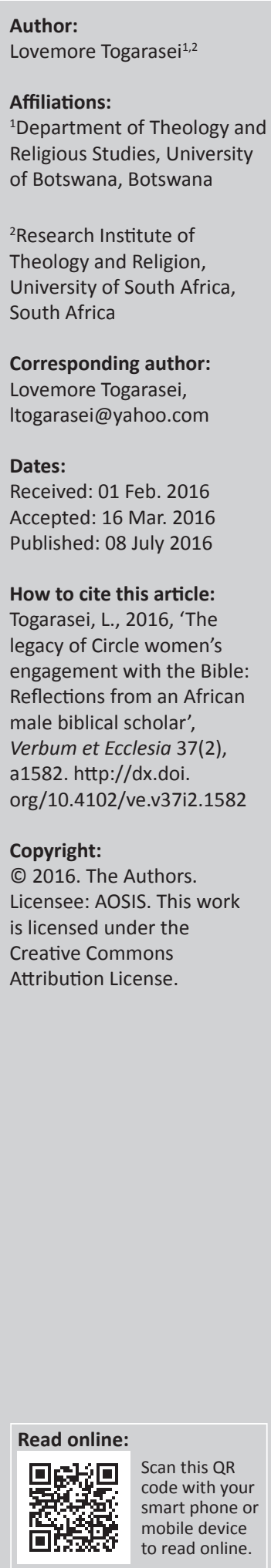

The entry of women into religious and theological studies has revolutionised the modus operandi of these disciplines. Especially with the formation of the Circle of Concerned Women Theologians, the study of these disciplines has never been the same. In this article, an attempt is made to consider the legacy of women theologians in the area of biblical interpretation. Specifically, the article looks at how members of the Circle have interpreted the Bible in their quest for a theology that responds to African women's experiences. The article discusses Circle biblical scholars' methods of interpreting the Bible, what they have managed to achieve, as well as pointing out areas that still call for attention. It concludes that Circle biblical scholars, like all African Biblical Interpretation, are engaged scholars who serve both the need for intellectual growth as well as solving the pressing needs of their societies.

Intradisciplinary and/or interdisciplinary implications: This article primarily focuses on how members of the Circle of Concerned Women Theologians have interpreted the Bible in their quest for justice. It therefore engages several disciplines: biblical interpretation, theology, gender, politics, health, and so on.

\section{Introduction}

I consider it a great honour to be invited to contribute to this article reflecting on the work of the esteemed daughters of Africa who have chosen to contribute to the development of mother Africa through theological reflection, an activity previously preserved for white male and middle class individuals. I consider it an honour as I believe my academic work, particularly in the field of gender and engaged biblical scholarship, has largely been shaped by the work of members of the Circle of Concerned Women Theologians. I remember as a student reading the works of Mercy Amba Oduyoye, especially the The Will to Arise which she edited with Musimbi Kanyoro and was published in 1992, while I was doing my first year at the University of Zimbabwe. But most importantly, Circle became very active when I was just entering the world of academics. The works of Circle members such as Musa Dube, Madiopane Masenya, and Isabel Phiri closer home, greatly influenced my thinking as I reflected especially on the subject of the Bible and HIV and AIDS. I would soon meet, work, and interact with a lot of the members, including Oduyoye herself, whom I met at a conference in Hamaanskraal, South Africa in 2003. Their influence on me over the years is invaluable. I therefore feel greatly honoured to reflect on the legacy of the Circle through this article. Let me begin by noting that some work has already been done in reflecting on the work of this organisation. Some reflections have been in form of self-introspection by members of the Circle, whereas others have been done by outsiders. As early as the seventh year of its inauguration, at the second pan-African conference in Nairobi, Kenya, in 1996, in her keynote speech, Musimbi Kanyoro (1997:7-27) outlined the objectives of the organisation and evaluated the work thus far. In 2004 an American scholar, Monohan, reviewed the work of the Circle focusing on the work already done on the four thematic areas chosen for research and reflection at the Circle meeting of 1996 in Nairobi, Kenya. Monohan (2004) considered the work, paying close attention to the works of Oduyoye and Dube, over and above the other two projects of the organisation. Ezra Chitando (2009) and Musa Dube (2009) both evaluated the work of the Circle focusing on their responses to HIV and AIDS. I shall consider all these works, but with my focus being on the work done in the area of biblical studies. Specifically, I look at how members of the Circle have interpreted the Bible in their quest for a theology that responds to African women's experiences. I therefore divide this article into four sections. In the first place, I look at the founding objectives of the Circle as a basis for evaluating the work. In the second section, I then focus on the general theological approach of the Circle before narrowing down to biblical studies work in the third section. Here I focus on the methodology used in the work and how this 
was informed by the objectives of the organisation. In the fourth section I then evaluate the legacy of the Circle from a biblical male scholar's perspective. A summary conclusion ties down the article.

\section{The Circle: The organisation, the objectives}

Stories are good both to tell and to listen to, especially those stories of success. However, I do not want to be tempted to spent time and space retelling the story of the Circle. Enough has been done. Suffice, however, to say that the story goes back to the late 1980s when Mercy Oduyoye started pushing the agenda of active participation of African women theologians at various theological bodies and gatherings resulting in the inauguration of the Circle in Ghana in 1989 (Kanyoro 1997:7-27). Ten objectives were set out to guide the work of the organisation. Again, I do not have space to outline them. Instead, I shall consider the spirit of all the ten as I prepare to consider how they influenced the work of Circle members' engagement with the Bible.

With the dominance of women in the religions of Africa abundantly clear, the main objective of the Circle was to bring the educated women in church leadership and in the academy to research and write on the experiences of African women so that the story of women could be told by women themselves. Thus Kanyoro (1997) states the objective of the Circle as follows:

The main objective of the Circle women is to write and publish theological literature written by African women from their experience of religion and culture on this continent. Research and writing for publication is our target and sole reason for being. Thus we are an academic group. We want to fill a gap in African women's profile as well as in theological writings from Africa. (p. 11)

To achieve this, the Circle has been working with a specific theology right from the beginning.

\section{Theological approach}

Systematic theologians ${ }^{1}$ have it that theology should be experienced or lived. This is the approach that guides the theology of members of the Circle. As Monohan (2004) accurately states:

Members of the Circle assess their experience of culture, religion, biblical interpretation, and social responsibility from a faith perspective. They tell of their pain and their triumph. They speak of their frustration in encounters with Western misinterpretation, negligence, and ignorance of the African female experience. Listening to the Circle is not a passive activity. They write in order to promote action and to participate in it. Theology for them is meaningless unless it is lived. (p. 2)

In fact, all members of the Circle are active participants in the faiths of Africa. A number are ordained ministers, others are

1.For example, Macquarrie (1977:1) who defines theology as 'the study which, through participation and reflection upon a religious faith, seeks to express the theologians in seminaries or university departments, and others work for Christian ecumenical organisations. Thus their theology engages the day to day experiences of people of faith in Africa. Their theology challenges communities the world over to reform, renew, or create behaviour that promotes the holistic living of the world community (Monohan 2004:2). Njoroge (1997:2) explains that the women do not address philosophical or abstract ideas, but rather, 'are dealing with today's life-threatening/destroying and lifegiving/affirming issues. Doing theology means wrestling with God's Word as we confront the powers and principalities of this world.'

Circle theology can be classified within African theology. Thus Mercy Oduyoye speaks of the objective of Circle theology as correcting the imbalance of African theology by doing a 'two-winged' theology (Kanyoro 2002:1). Using the image of a flying bird, Oduyoye explains that theology without the faith reflections of women is like a bird with only one wing, disabled and unable to take to the air. Oduyoye (1995:174) believes, 'personal experiences are a valid source for understanding gender issues in the organization of human society'. It is this personal experience that members of the Circle use as they engage theology. As an organisation, the Circle works by identifying specific themes to pursue. As stated above, I am here interested in the theme of the interpretation of scriptures by members of the Circle.

\section{The use of the Bible in Circle work}

Circle's use of the Bible can be located within what has come to be called African Biblical Interpretation/Hermeneutics (ABI). ${ }^{2}$ The history of ABI goes back to the 1970s when, following the independence of many African states, an attempt was made to read the Bible for the African context. Although, many of the African biblical scholars had been trained in the West and specialised in teaching the methods of Western biblical interpretation, these scholars began realising the emptiness of their teaching and research as long as these did not speak to the context of their people. A good summary of historical developments in biblical studies in Africa is given by Justin S. Ukpong (2000:11-28). Ukpong divides the history of biblical interpretation in Africa into three phases. ${ }^{3} \mathrm{He}$ describes as the first phase the period from the 1930s to the 1970s when African biblical scholarship was reactive and apologetic, focusing on legitimising African religion and culture. The second phase for Ukpong is the period from the 1970s to the 1990s when African biblical scholarship was both reactive and proactive, using the African context as a source for biblical interpretation. The last phase began in the 1990s, dominated by liberation and inculturation methodologies, recognising the ordinary readers of the Bible and also taking the African context as the subject of biblical interpretation. It is in this third phase that the work of the Circle falls.

2.I shall use ABI to refer to biblical interpretation in Africa. ABH is often used to refer to the group of African or Africanist biblical scholars meeting every year at the Society of Biblical Literature annual meetings in United States of America. 3.The three phases Ukpong refers to are those phases when the concern of biblical
interpretation was to create an encounter between the biblical text and the African interpretation was to create an encounter between the biblical text and the African
context. Otherwise it is possible to talk of five phases if one includes the phase of context. Otherwise it is possible to talk of five phases if one includes the phase of
allegorisation during the patristic age and the phase of the historical critical method. 
The starting point for Circle members' approach to biblical interpretation (and this is true of most African biblical scholars) is the rejection of the historical critical approach's emphasis on privileging of the author and the author's world in determining meaning of texts. They challenge the traditional distinction of exegesis and eisegesis convicted that biblical texts have multiple meanings (Dube 2004:50). Thus Anderson (2003) says:

the Bible must be interpreted with an awareness of both the theological implications of the biblical text and the social location of the community within which the text is read. (p. 24)

Circle members believe that each biblical text can have as many meanings as the readers and the methods they use. Methods of interpretation are then determined by the social conditions of the readers or interpreters. Based on these convictions, Circle members have therefore used a number of methods of biblical interpretation depending on issues that they seek to address. Below I discuss some of the methods they have used.

\section{Reading with non-academic readers}

The work of the Circle in the area of biblical studies began when some people had already started expressing disappointment with the historical critical method (Powell 1999; Randolph Tate 2006; Saayman 2005). As Bosch observed then, biblical scholarship had become a highly specialised and sophisticated science (Saayman 2005:205-213). The historical critical method's emphasis on the world of the text and the original meaning of the text kept the biblical texts in their original world with little or no meaning to the modern readers. It kept the Bible as the property for intellectual readers only. Circle reading of the Bible challenge this methodology out of the naked truth that, in Africa, most of the users of the Bible are not schooled in the 'critical' reading of the Bible. Circle scholars who challenged this include Anderson (2003:23-43), Dube (2004), Kanyoro (1997:363378), and Plaatjie (2001:114-144). They recognised the importance of such ordinary (non-academic) readings of the Bible and sought to bring them into the academic interpretation of the Bible. Dube (2004:50) would say, 'If all reading is socially conditioned, academic interpretations may be no "better" than readings of untrained readers'. Dube (1996a) tells us how she came to read with non-academics:

The story of how I come to 'read with ordinary readers' is about my long walk in a hall of mirrors. As a black Motswana African woman, I am indeed privileged to be admitted in this hall of magnificent mirrors; I have, nevertheless, struggled to see my image. Its mirrors occasionally give me a piece of what should be my face, and it is usually something undesirable. (p. 10)

The method of 'reading with' brings the academic reader to the community and allows a collaborative reading. As Ukpong (2002) puts it:

Through such a process the academic reader accesses the resources of popular readings of the Bible and the academic scholarship is informed and enriched by the resources outside its circle, while the ordinary readers acquire the perspective of critical reading. (p. 24)
Kanyoro (1995), while calling her approach cultural hermeneutics, explains the advantages of reading with nonacademic readers. She believed that the method allows for a forum in which non-academic Christian women can speak about their life experiences.

\section{Postcolonial Biblical interpretation}

This method was also pioneered in Africa by Circle scholars. Dube is one such pioneer of the use of postcolonial theory for biblical interpretation in Africa. She did this first in her doctoral thesis, later published as a book entitled, Postcolonial Feminist Interpretation of the Bible, published by Chalice Press in 2000. Although earlier African theologians like Mercy Oduyoye had worked on the area of cultural criticism, as Kwok Pui-lan correctly observes, they did not, 'draw explicitly from the theoretical framework of postcolonial theory' (Pui-lan 2004). Dube explicitly did this, drew from the postcolonial theory and interpreted the Bible in Africa in the light of the theory.

For example, in the Postcolonial Feminist Interpretation of the Bible, Dube uses the theory to argue that for the Two-Thirds World subjects, the Bible is imperialistic. She links this to the popular African saying, 'When the white man came to our country he had the Bible and we had the land. The white man said to us, "let us pray". After the prayer, the white man had the land and we had the Bible' (Dube 2000a:3). She then suggests that it is only a postcolonial reading of biblical texts that can liberate readers from this imperialistic oppression (Dube 2000a:198-199). In fact, in another article on postcolonial biblical interpretation, Dube argues that the use of the theory is imperative for Africans. Referring to postcolonial biblical interpretation as 'reading for decolonization', Dube (2002) insists:

Reading the Bible and other cultural texts for decolonization is, therefore, imperative for those who are committed to the struggle for liberation. While the Bible is a usable text in imperial projects, how it should be read in the light of its role are central questions to the process of decolonization and the struggle for liberation. As a Motswana woman of Southern Africa, my reading for decolonization arises from the historical encounter of Christian texts functioning as the 'talisman' in imperial possession of foreign places and people. (p. 60)

In the same article, Dube (2002:51-75) then interprets John 4:1-42 using the postcolonial theory. She concludes that biblical critical practice must be dedicated to an ethical task of promoting decolonisation, fostering diversity, and imagining liberating ways of interdependence.

\section{Feminist Biblical interpretation}

This is the most common approach used by Circle biblical scholars because of their engagement with gender. From its beginning, feminist biblical interpretation has not been a single method. It has always been multimethodical. Thus Patricia F. Bruce (2003:44-70) addresses issues of gender as she analyses Old Testament references to virginity in the context of HIV and AIDS in South Africa. Although she 
mentions her approach as contextualisation, distantiation, and appropriation, the lenses she uses in her analysis are feminist. She concludes that if the church is to advocate virginity it has to do so on grounds that are not harmful to women.

Circle scholars' feminist biblical interpretations have not been limited to academic circles, theorising, and debating sources and forms. The scholars have interpreted the Bible to address what women in Africa both in church and outside the church are experiencing. For example, interpreting the story of the Samaritan women (John 4:1-42), Dube (2001a:3-24) compares the experience of the Samaritan woman (marriage to five different husbands) to what many African women are experiencing: poverty and starvation, violent civil and ethnic wars, oppressive international financial policies, HIV and AIDS. Thus through biblical interpretation, Circle scholars have fought for the liberation of the African woman.

The story of the Samaritan woman is also used by Umeagudosu (1997:17-18) who is of the opinion that some biblical texts have been interpreted in a way that sacralises the earth and in the process gives rise to a multitude of taboos which are inimical to women's well-being. She therefore suggests a reinterpretation that leads to the conclusion that:

... in God's commonwealth, men and women should see themselves as co-stewards, caretakers and managers. Human beings should see themselves as aliens, who by God's love have equal rights and privileges in one God. (Umeagudosu 1997:18)

The same line of argument is taken by Udo (1997:20-25) who focuses on texts that show the equality of men and women. There is no attempt to address those texts that show inequality. Other Circle biblical scholars who use the feminist lenses are Masenya (2001:145-158) and Nadar (2001:159-175) who do so using a womanist approach.

\section{Divination}

Divination as a method of biblical interpretation is a typically African or even Southern African method of reading the Bible. For academics it is a method that develops from reading with non-academic readers of the Bible. Dube is the Circle scholar who has brought academics' attention to this method of reading the Bible (2000b:67-80; 2006:193-207). She came across this method as she read the Bible with Botswana women in African Independent Churches (AICs). The method is influenced by the African practice of throwing bones to diagnose human problems and to find answers to these problems. Dube noted that in the same way bones or other such divining objects were used by traditional healers, Christians in AICs used biblical texts. Instead of throwing bones, AIC prophets would hand the Bible to the patient, ask her to open whatever text and hand it back to the prophet. Through interpretation of the opened text the prophet then divines the problems of the patient and offers the remedy.

Dube then interprets biblical passages through this method. In the story of the Canaanite woman (Mt 15:21-28), Dube sees the story of international relations. She divines the Canaanite woman as representing African leaders going to the Western world (Jesus) to beg for aid and foreign direct investments. In the same way that Jesus says children's bread must not be given to dogs, Western powers consider aid to Africa as throwing money into a bottomless pit (2006:203). It is only through the woman's insistence and Jesus' realisation of her faith that her daughter is healed. Dube then concludes that it is only through the combined effort of the Western world and the Two-Thirds World that, international relations for the good of all humanity can be improved.

\section{Storytelling and social location}

This is a common method used by members of the Circle. The book, Her Stories: Hidden histories of women of faith in Africa, edited by Phiri, Govinden and Nadar (2002), is full of such stories. As Dube (2001b:3) states in her introduction to Other Ways of Reading, stories and storytelling are central to African societies. Circle women therefore make use of this method in interpreting biblical texts. Rose Teteki Abbey (2001:23-26) uses the method to enter the biblical narratives of women retelling them as the concerned women: the Samaritan woman, the woman caught in adultery, and Mary the sister of Martha and Lazarus. She tells the stories in a way that directly addresses the factors that affect contemporary women in Africa: prostitution due to difficult economic conditions, abusive husbands, societal negative stereotyping of women, etc. She therefore advocates for a biblical interpretation which makes use of African tales or one which uses African methods of storytelling. Masenya (2001:27-49) and Dube also use the same approach to address issues that affect Africa and its people, particularly women. Masenya compares biblical stories in the Hebrew Bible with African stories (Northern Sotho in South Africa specifically). She retells the stories in a way that helps the illiterate, and at the same time gives women techniques of survival and resistance.

Circle biblical scholars also use storytelling together with social location. A social location is the context(s) within which individuals understand, make judgments, value, and think (Tate 2006:340). Such a context can be biological, educational, cultural, ideological, or even religious. It is on the basis of social location that Dube (2001b:60) strongly argues for storytelling as a method of biblical interpretation in Africa. This is because, as she correctly observes, 'all readers interpret the text according to their social experiences.' This way she therefore reads the story of the woman with haemorrhage in the context of an oral African tale of a young girl buried by her friends, but who sings from her grave telling her story. She takes this young girl to be Africa and tells the story of Africa's dispossession from colonialism to globalisation. She also uses the method to interpret the story of the Samaritan woman (Jn 4:1-42), comparing the story of this woman to that of African women and the African land (Dube 2001b:42-65). She compares the Samaritan woman's experience with 
many husbands to Africa's economic and political crises under foreign and local political powers.

\section{HIV and AIDS reading of the Bible}

The Circle, in general has done a lot of work on HIV and AIDS. Between 2002 and 2006, five books were published focusing on HIV and AIDS and religion and culture (Dube 2009:173-196). I shall here focus on biblical interpretation in contexts of HIV and AIDS. Dube is one Circle scholar who has made significant contribution to biblical interpretation in Africa, in contexts of HIV and AIDS. Dube has read the Bible for HIV prevention, treatment, care, and destigmatisation. She has also written to address social and cultural factors that tend to promote the spread of HIV: gender inequality, child abuse, poverty, violence, international injustice, age, race, and ethnic discrimination.

Landman (2004:276) calls the church and society that are guided by the teaching of the Bible to make use of biblical texts like Leviticus 15, 'to embrace the option of inclusion, interrelatedness and non-stigmatisation as values.' She also uses the book of Job to call those living with HIV not to see themselves as victims but as survivors. She finds three insights for people living with AIDS in Job: not trying to change the past, being God's friend, and asserting oneself as a worthwhile human being (Landman 2004:278). Landman also stresses the 'however theology' in Habakkuk. This theology says that though you might be experiencing suffering, God has not abandoned you but rather stands with you. It is a theology that people living with HIV and AIDS (PLWHA) need especially in light of the absence of a cure. Landman discusses many other biblical texts both from the Old Testament (OT) and from the New Testament (NT) that can be used to positively respond to HIV and AIDS. What comes out clear from Landman's hermeneutics is interpretation of the Bible to promote life. She accepts the fact that readers of the Bible approach it with specific questions which have a result to what they find in the Bible. There are questions that can make HIV and AIDS stronger and thus 'kill' the infected and those that make HIV and AIDS weaker and thus give life to PLWHA. Biblical interpreters should then help readers and users of the Bible to concentrate on questions that bring life.

Other Circle scholars who have engaged the Bible for HIV response are Anderson (2003:23-43), Bruce (2003:44-70), and Akintunde (2003:96-110). A full Circle volume, Grant Me Justice: HIV/AIDS and Gender Readings of the Bible (Dube and Kanyoro 2004), was dedicated to biblical interpretation in contexts of HIV and AIDS. In this volume eight women biblical scholars engaged different biblical texts suggesting ways of rereading these texts in response to the threat of HIV and AIDS. In light of theirs and other scholars who have engaged the Bible for HIV and AIDS response, Togarasei (2008) called for a methodology called HIV and AIDS reading of the Bible.

\section{A male biblical scholar's reflection on Circle work}

Let me begin my reflection by sharing the story of my journey with the Bible. ${ }^{4}$ This is because it is this experience with the Bible that I use to discuss the work of Circle biblical scholars.

\section{Growing up}

I cannot remember when I was first introduced to the Bible. All I know is that I grew up knowing more biblical stories than traditional folklore. With my parents being Christians, I remember the many times when the Bible was read to me before I was disciplined. 'He who spares the rod hates his son, but he who loves him is diligent to discipline him' (Pr 13:24), my father would read to me. Often moral lessons were punctuated with quotations and/or examples from the Bible. I remember one day my mother reading me 1 Corinthians 15:33, 'Bad company ruins good morals,' when she met me in the company of a group of young boys who were known for bad behaviour in the village. The same continued when I went to school. Both at assembly and in class during scripture lessons, the Bible was read to inculcate morality in us.

\section{'Take a biblical name, drink no Coke and eat no bread': First conversion and baptism}

When I was born my parents were Christians. They, however, left the religion for some time, frustrated by their pastor after he was accused of adultery. But with the seeds of Christianity having been sown in me early, by the age of 13 I got converted to one of the many Zionist churches that operated in our village. Here I encountered a new reading of the Bible. At my baptism I was asked to take a biblical name as 'Lovemore' was considered unbiblical. As converts, we were also told not to drink Coca Cola as it was believed to be made from tobacco. Drinking it was just as good as smoking, which was again condemned. We were not supposed to eat bread from the shops as the Bible teaches, 'Avoid leaven'. All Western medication was considered unbiblical as one was supposed to be healed through faith in God. We were not to eat pork and were supposed to observe the full law of clean and unclean food in accordance with Deuteronomy and Leviticus. Later when I was introduced to postcolonial readings of the Bible, I realised that, existing during the colonial period in Zimbabwe, there was a lot of anti-colonial reading of the Bible in this church. The teaching was, as much as possible, meant to discourage everything associated with our colonial masters. A decade before I was converted, the church was even teaching against Western education.

\section{'They read the Bible wrongly': Conversion after conversion}

My village was home to a number of other Christian denominations. At the local store, in the pastures herding cattle, at the swimming ponds and grinding mills, people would often debate the right or wrong readings of particular churches with members of the different churches supporting 4.I first told this story in the book, Bible in Context: Essays collection (Togarasei 2009). 
their own readings. The Bible was the yardstick for proving the wrongness or the rightness of the teaching and practices of specific churches. So central was it that memorising its verses and citing them correctly in debates was to some extent a measure of spirituality.

One church that underlined the place of the Bible in its teaching and practice is the church I currently belong to: Church of Christ in Zimbabwe. At the age of 18 I was 'reconverted' to this church when its members convinced me that the Zionist Church I belonged to, 'read the Bible wrongly' in many ways. Firstly, they were wrong in baptising people in the name of the Father, the Son, and the Holy Spirit (for everywhere people were baptised in the NT, they were baptised in the name of Jesus). They were also wrong in calling followers of Jesus 'Zionists' because belief in Jesus makes one a Christian, not a Zionist (Ac 11:26). They were also wrong, I was told, in teaching against the consumption of bread, pork, Coke, and so on, 'For everything created by God is good, and nothing is to be rejected if it is received with thanksgiving' (1 Tm 4:4). The list of the wrong readings was long and having been taught early that, 'All Scripture is inspired by God for correction ...' (2 Tm 2:16), I was left without any doubt that we were 'reading the Bible wrongly'. I therefore got converted and had to be baptised in the name of Jesus.

\section{'These are myths and legends': Encounter with the academic study of the Bible}

My whole early childhood was so characterised by Bible study that when I took Divinity for my Cambridge Advanced Level examinations, I passed it with an A grade. So when I enrolled for my Bachelor of Arts degree, I decided to study Archaeology and Religious Studies. Having chosen Religious Studies I came face to face with the academic study of the Bible. 'Spiritually challenged' is the best way I can explain my response to the course, 'Introduction to the Old and New Testaments.' My two lecturers, who were both trained by German scholars, were very much influenced by the historical critical method of biblical interpretation. I learnt that the books of the Bible were canonised through a process of selection and rejection. 'The Bible did not fall down from heaven,' I came to know. I learnt that even the process of selection and rejection was not that transparent. I learnt about Julius Wellhausen's four documentary hypothesis with the implication that the biblical books were composed in specific historical and cultural situations to address the needs of the compilers, collectors, authors and editors. Through a form critical analysis of the books of the Pentateuch and the Gospels, the stories of Moses and Jesus and many other biblical figures were treated as myths and legends.

\section{Plural methods of interpretation}

As I continued with biblical studies, I soon realised that there was no one approach to biblical interpretation. Although my teachers had introduced the historical critical method as the method, they later introduced us to other methods such as reader response criticism, rhetorical criticism, social scientific approaches, feminist criticism, and so on. In studying the rise of the different methods we also realised that each method was influenced by the circumstances in which the proponents of the method were when they introduced it. For example, the historical critical method was a result of the Enlightenment period's emphasis on science and empirical evidence. Thus I soon came to learn that there are plural methods of biblical interpretation as people read the Bible in different contexts and interpret it for different reasons.

\section{But what does the Bible mean to me and my community: Engaged scholarship}

As I continued with biblical studies at postgraduate level, I began to feel unsatisfied with the results of the academic study of the Bible. I felt that something was missing in the sense that we were not providing readers of our works with any form of personal empowerment. My feeling then is best expressed by L. Alonso Schockel (cited by Sugitharajah 1991):

People ask us for bread and we offer them a handful of theories about each verse of John 6. They ask questions about God and we offer them three theories about the literary form of one Psalm. They thirst for justice and we offer the discussions about the root word sedaga (justice in Hebrew). I am examining my conscience out loud, and the reply I hear is: the one must be done without neglecting the other. (p. 7)

Thus, in my very first published work, I interpreted 1 Timothy 2:9-10 and 1 Peter 3:3-4 under the subject of women's dress code in some Zimbabwean churches (Togarasei 2002a). This was followed by another article on teaching the Old Testament in contexts of HIV and AIDS (2002b). The rest is history. My work has generally been on the Bible in African Christianity addressing issues that I consider to be of relevance to the visions, aspirations and challenges Africa is facing. I therefore discuss the work of Circle biblical scholars below in light of this background.

\section{Reflection}

The work of Circle biblical scholars can be described as revolutionary in all senses. To start with, they rejected the traditional approach to biblical interpretation, which is exegesis. As we have seen in the work of Anderson, cited above, they rejected the historical critical approach's claim for objectivity. Circle scholars have also been revolutionary in coming up with methodology that fits into African traditions and ideologies. As another male scholar observed many years ago while reflecting on the work of Circle scholars, 'The contributors (Circle scholars) are clearly seeking to move us beyond the familiar situation in which the data are African and local but the analytical theories and methods must come from elsewhere' (Maluleke 2001:242). As we have seen above, Circle biblical scholars have come up with new methodologies and theories in the form of storytelling, divination, HIV, and AIDS biblical interpretation and so on. This is indeed commendable as every scholarship worth the name must be strong in its analytical theories, methods, and tools. 
In her analysis of the work of Circle in general, Monohan (2004:8) commended the organisation for its holistic theology. This is true of the biblical scholars as well. Their interpretation is meant for flesh and blood readers and users of the Bible in the contemporary context. Thus no single approach is used for biblical interpretation. Instead, members use various approaches: reading behind the text, reading the text itself, and reading in front of the text with the guiding objective being to facilitate individual and societal well-being. For different reasons, the Bible is an esteemed and revered book in Africa. People strive to live by what it teaches. It is therefore important to use it as an entry point for addressing issues that affect Africa.

But Circle biblical scholars are also very much aware of the potential of the Bible to cause harm and indeed its history in harm dealing in Africa. Most of them point out the patriarchal origin and nature of the Bible. In their interpretation, they therefore are vigilant in bringing issues of African women to the fore. They then choose to use methodologies and interpretations that liberate and promote life over those that are life-depleting and oppressive.

Circle members also address the realities of Africa as they read the Bible: hunger, child and women abuse, globalisation and its accompanying death dealing policies, HIV and AIDS, and so on. They do not end with matters of intellectual curiosity but do so as they address bread and butter issues. I am reminded of a story of a man who was asked what decisions he makes in the home and what decisions are left to his wife. The man mentioned all decisions to do with food, where to live, when to go on holiday, which schools to send children to, what investments to make for the family, and all other decisions that affect the family as the reserve of his wife. Asked what decisions then he made, he responded, 'Predicting world foreign policies like when America is likely to bomb Iraq!' Although this is possibly just a joke, it really gives us the picture of how women are concerned with the realities of life rather than abstractions. This is very evident in the work of Circle biblical scholars.

Circle scholars undertake their biblical interpretation taking seriously the religious faith of Africa. They specifically address the Church in their interpretation. They are confessional and declare their social location when interpreting biblical texts. Take, for example, Kgalemang (2004) who, while interpreting John 9 in order to deconstruct HIV and AIDS stigma, says:

... HIV / AIDS is in our midst, digs deep within us that the 'hour has struck' for a genuine Christian response ... we must not be judgmental of those who suffer from AIDS ... (p. 165)

There is the owning of the problem and a strong conviction that Christianity can provide a solution. Biblical interpretation is therefore guided by this strong Christian conviction.

Circle members also theologise from ecumenical and interfaith perspectives (Monohan 2004:8). Biblical scholars therefore take an interfaith approach to theology. The Circle has members who practice Islam as well as African traditional religions. Circle gatherings also bring together participants from the different churches in Africa, ecumenical councils of churches, and the academia. This spirit of unity needs to be commended in a continent that experiences religious-based conflicts.

As an academic in the area of biblical studies, one of the major contributions of the Circle is promoting the generation of knowledge through research and publications. In the 1960s and 1970s, the few African academics realised how much African curriculum was foreign or specifically Western. Thus Chitando (n.d.) says:

... almost all disciplines in universities have been dominated by ideologies, perspectives, interests and approaches from the global North. What has been deemed 'standard scholarship' has invariably consisted of rehashing formulae developed in western contexts. (n.p.)

The only way to counter this is to research and publish ideologies, perspectives, interests, and approaches from Africa. Members of the Circle have made a significant contribution towards this noble vision. By 2002, the Circle had 31 books not counting the tens of articles in journals, chapters in books, and other publications on or responding to some Circle publications. ${ }^{5}$

As I end my reflection, let me point out a few areas I think Circle can strengthen as we go forward. The first area is the engagement of men in the work of the Circle. HIV has shown us that men and women cannot work in isolation. Having spent years attacking men for the spread of HIV through their abuse of women, in the last few years, scholars have realised the need to positively engage men instead of continuously pointing out their weaknesses. Ezra Chitando and Sophia Chirongoma's (2012) book on Redemptive Masculinities is one book, amongst others, that has opened this method of engaging men. I am not calling for Circle to open up for male membership, but to continue inviting men to theologically reflect with them.

Another area that the Circle has to engage with is same-sex sexualities. This is a topic that has not received enough attention from Circle biblical scholars. Whether for or against, this is a topic we cannot avoid addressing as biblical scholars and theologians. This is because different perceptions about the practice are deeply rooted in the Bible. And while on the same subject, I am thinking of the implications of accepting people of different sexual orientations to the identity of the Circle which until now was an association of women theologians. Discourses of sexuality, especially as pushed by

5.Some of the publications are: Transforming Power edited by Oduyoye (1997) Where God Reigns edited by Amoah (1997), Other Ways of Reading edited by Dube (2001b), Her Stories edited by Phiri et al. (2002), African Women, HIV/AIDS and Faith (2001b), Her Stories edited by Phiri et al. (2002), African Women, HIV/AIDS and Faith Communities edited by Phiri, Haddad and Masenya (2003), People of Faith and the Challenge of HIV/AIDS edited by Oduyoye and Amoah (2004), Grant Me Justice edited by Dube and Kanyoro (2004), Talitha Cumi edited by Njoroge and Dube (2001), The Will to Arise by Oduyoye and Kanyoro (1992), African Women, Religion and Health edited by Phiri and Nadar (2006). Bibliographical details of these works are in the bibliography. The list of other works that touch on various aspects of Circle work are too numerous to mention here. 
those of the Lesbian, Gay, Bisexual, and Transgender (LGBT) community, no longer accept the male-female dichotomy as the basis of sexual identity.

The issue of the diversity of African women has been raised by Monohan (2004:9). She said with more than 150 denominations of Christianity present in Africa (and I believe they are more than that), the diversity within Christianity itself is a serious issue posing its own set of challenges to Circle's ecumenism. She therefore suggested that the Circle must take racial or ethnic and cultural diversities seriously as these are part of the reality of the continent of Africa. With our history of colonialism and the mobility of globalised societies, Europeans and Asians (of late in the form of Chinese immigrants) claim a homeland in Africa as well. Their presence means we need to invent new ways of biblical interpretation which are inclusive of all.

I believe we still need biblical scholars who are well grounded in the exegesis of texts. If we are to use the Bible successfully and constructively without allowing the Bible to say whatever the interpreter wants it to say, we still need detailed studies of the Bible in its original languages. We need to do so, however, using both the Greek and Hebrew resources to analyse our modern translations both in English and in the African vernacular languages. The abuse of the Bible is quite evident in the so-called prosperity gospel which seems to attract women more than men as has always been characteristic of Christianity. This is not a call for a return to the historical critical method only, but in the words of Schoeckel (cited above), so that 'the one must be done without neglecting the other'.

African female biblical scholars have also not touched one subject that I think oppresses women in Africa. This is the issue of lobola. I discuss this issue in the context of Paul, the Apostle, suggesting that African Christians need to discourage this practice (Togarasei 2012). I have faced criticism whenever I raise the issue although I still think I am justified to make the call. I would be happy to hear what African female biblical scholars think of this subject.

Let me end by posing the last challenge not only to Circle biblical scholars but to all African biblical scholars. I have already commended Circle scholars for suggesting theories and methodologies for interpreting the Bible in Africa. Proposing theoretical frameworks for interpreting the Bible in Africa is still very much required. I believe, we have not really outlined our modus operandi when it comes to biblical interpretation. This is more apparent in feminist biblical interpretation (but of course not limited to it). There are times when we hold the Bible dear, proposing that it provides solutions to problems that we face, but there are also times (many of them) when we accuse it of causing problems amongst us. This double standard makes our scholarship weak and does not differentiate us from other ordinary users of the Bible whom we often accuse of selective reading of the Bible for selfish reasons. How then should we proceed? Elsewhere (Togarasei 2008), drawing from the work of
African biblical scholars in general and Circle biblical scholars in particular, I have proposed that biblical interpretation should be guided by four principles: to save life, to seek justice for all, to promote love, and to liberate the marginalised. Does this approach serve our purposes and provide a strong theoretical grounding?

\section{Conclusion}

Our postmodern world with its rejection of grand narratives calls for the approach that ABI in general and Circle in particular have adopted. The historical critical approach's quest for objectivity in interpretation can no longer be sustained in a world where all deserve to express themselves and to be heard. In this article I have looked at Circle biblical scholars' methods of interpreting the Bible. I have looked at what they have managed to achieve as well as pointing out areas that still call for attention. It can be concluded that Circle biblical scholars, like all ABI, are engaged scholars who serve both the need for intellectual growth as well as solving the pressing needs of their societies.

\section{Acknowledgements Competing interests}

The author declares that he has no financial or personal relationships which may have inappropriately influenced him in writing this article.

\section{References}

Abbey, R.T., 2001, 'I am the Woman', in M.W. Dube (ed.), Other ways of reading: African Women and the Bible, pp. 23-26, SBL, Atlanta.

Akintunde, D.O., 2003, "The attitude of jesus to the "Anointing Prostitute": A mode for Contemporary Churches in the face of HIV/AIDS in Africa', in I.A. Phiri, B. Haddad \& M. Masenya (eds.), African Women, HIV/AIDS and faith communities, pp. 94-110, Cluster Publications, Pietermaritzburg.

Amoah, E. (ed.), 1997, Where god reigns: Reflections on Women in God's World, SamWoode Ltd, Accra.

Anderson, C.B. 2003, 'Lessons on healing from Naaman (2 Kings 5:1-27): An AfricanAmerican Perspective', in I.A. Phiri, B. Haddad \& M. Masenya (eds.), African Women, HIV/AIDS and faith communities, pp. 23-43, Cluster Publications, Pietermaritzburg.

Bruce, P.F. 2003, 'The Mother's Cow: A study of old testament references to virginity in the context of HIV/AIDS in South Africa', I.A. Phiri, B. Haddad \& M. Masenya (eds.), African Women, HIV/AIDS and faith communities, pp. 44-70, Cluster Publications, Pietermaritzburg.

Chitando, E. (n.d.) 'The Africanisation of Biblical Studies in Zimbabwe: Promises and challenges', unpublished paper, author's collection.

Chitando, E., 2009, Troubled but not destroyed, WCC, Geneva.

Chitando, E. \& Chirongoma, S. (eds.), 2012, Redemptive masculinities: Men, HIV and Religion, WCC Publications, Geneva.

Dube, M.W., 1996a, 'An introduction: How we came to "Read With"', Semeia 73, 7-17.

Dube, M.W., 2000a, Postcolonial feminist interpretations of the Bible, Chalice Press, St Louis.

Dube, M.W., 2000b, 'Divining Ruth For international relations', in K.A. Adam (ed.), Postmodern Interpretations of the Bible, pp. 67-80, Chalice Press, St Louis.

Dube, M.W., 2001a, 'Little girl, get Up: An introduction', in N. Njoroge \& M.W. Dube (eds.), Talitha Cum! Theologies of African Women, pp. 3-24, Cluster Publications, Natal.

Dube, M.W., 2001b, 'Fifty years of bleeding: A storytelling feminist reading of mark $5: 24-35$ ', in M. W. Dube (ed.), Other ways of reading: African Women and the Bible, pp. 50-62 SBL, Atlanta.

Dube, M.W., 2002, 'Theological challenges: Proclaiming the fullness of life in the HIV/AIDS and global economic Era', International Review of Mission XCI (363), 535-549.

Dube, M. W., 2004, 'Current issues in Biblical Interpretation', in J. Galgolo \& G. Marquarnd (eds.), Theological Education in Contemporary Africa, pp. 39-61, Zapf, Eldoret. 
Dube, M.W., 2006, 'Divining texts for international relations, Matthew 15:21-28', in E.P. Antonio (ed), Inculturation and postcolonial discourse in African theology, pp. 193-208, Peter Lang, New York.

Dube, M.W., 2009, 'HIV and AIDS research and writing in the circle of African women theologians 2002-2006', in E. Chitando \& N. Hadebe (eds.), Compassionate circles: African women theologians facing HIV, pp. 173-196, WCC, Geneva.

Dube, M.W. \& Kanyoro, M. (eds.), 2004, Grant me justice! HIV/AIDS and gender readings of the Bible, Cluster, Pietermaritzburg.

Kanyoro, M.R., 1995, 'Cultural hermeneutics: An African contribution', in O. Ortega (ed.), Women's visions: Theological reflection, celebration, action, pp. 18-28, WCC, Geneva.

Kanyoro, M.R., 1997, 'Celebrating god's transforming power', in M.A. Oduyoye (ed.), Transforming power: Women in the household of god (Proceedings of the Pan-African Conference of the Circle of Concerned African Women Theologians), pp. 7-27, Sam-Woode Ltd, Accra.

Kanyoro, M.R., 2002, 'Beads and strands: Threading more beads in the story of the circle', in I.A. Phiri, D. B. Govinden \& S. Nadar (eds.), Her stories: Hidden histories of women of faith in Africa, pp. 15-38, Cluster Publications, Pietermaritzburg.

Kgalemang, M., 2004, 'John 9: Deconstructing the HIV/AIDS Stigma', in M.W. Dube \& M. Kanyoro (eds.), Grant me justice! HIV/AIDS and gender readings of the Bible, pp. 141-168, Cluster, Pietermaritzburg.

Landman, C., 2004, 'The Bible as the source of healing and wellness for women affected by HIV/AIDS', in M.A. Oduyoye \& E. Amoah (ed.), People of faith and the challenge of HIV/AIDS, pp. 270-290, Sefer Books Ltd, Lagos.

Macquarrie, J., 1977, Principles of Christian Theology, Charles Scribner's Sons, New York.

Maluleke, T.S., 2001, 'African "Ruths," Ruthless Africas: Reflections of an African Modercai', in M.W. Dube (ed.), Other ways of reading: African women and the Bible, pp. 237-251, SBL, Atlanta.

Masenya, M., 2001, 'Esther and Northern Sotho stories: An African-South African Woman's Commentary', in M.W. Dube (ed.), Other ways of reading: African women and the Bible, pp. 27-49, SBL, Atlanta.

Monohan, B.M., 2004, Writing, sharing, doing: The circle of concerned African women theologians, Electronic Thesis, Boston College University, Boston.

Nadar, S. 2001, 'A South African Indian Womanist Reading of the Character of Ruth', in M.W. Dube (ed.), Other ways of reading: African women and the Bible, pp. 159-178, SBL, Atlanta.

Njoroge, N.J., 1997, 'The missing voice. African women doing theology', Journal of Theology for Southern Africa. 99, 77-83.

Njoroge, N. \& Dube, M.W. (eds.), 2001, Talitha Cum! Theologies of African Women, Cluster Publications, Natal.

Oduyoye, M.A., 1995, Daughters of Anowa: African women and patriarchy, Orbis Books, Maryknoll, NY.

Oduyoye, M.A., 1997, (ed.), Transforming power: Women in the household of god, Proceedings of the Pan-African Conference of the Circle of Concerned African Women Theologians, Sam-Woode Ltd, Accra.
Oduyoye, M.A. \& Amoah, E. (ed.), 2004, People of faith and the challenge of HIV/AIDS, Sefer Books Ltd, Lagos.

Oduyoye, M.A. \& Kanyoro, M., 1992, The Will to Arise, Orbis, Maryknoll, NY.

Phiri, I.A., Govinden, D.B. \& Nadar, S. (eds.), 2002, Her stories: Hidden histories of women of faith in Africa, Cluster Publications, Pietermaritzburg.

Phiri, I.A. \& Nadar, S. (eds.), 2006, African Women, Religion and Health, Cluster Publications, Pietermaritzburg.

Plaatjie, G.K., 2001, 'Toward a post-apartheid black feminist reading of the Bible: A case of Luke 2:36-38', in M.W. Dube (ed.), Other ways of reading: African case of Luke 2:36-38', in M.W. Dube (ed.), Other ways of reading: Africa
women and the Bible, pp. 114-142, Society of Biblical Literature, Atlanta.

Powell, M.A., 1999, The new testament today, Westminster John Knox Press, Louisville, $\mathrm{KY}$.

Pui-lan, K., 2004, 'Mercy Amba Oduyoye and African Women's theology', Journal of Feminist Studies in Religion 20 (1), 3-20.

Randolph Tate, W., 2006, Interpreting the Bible: A handbook of terms of methods, Hendrikson Publishers, Peabody.

Saayman, W., 2005, 'New testament studies and missiology in South Africa: Uneasy bedfellows?', Missionalia 33(2), 205-213.

Sugitharajah, R.S., 1991, Voices from the margin: Interpreting the Bible in the Third World, SPCK, London.

Togarasei, L., 2002a, 'Women, Adorn yourselves modestly!': Interpretative problems of 1Timothy 2:9-10 and 1Peter 3:3-4 in Zimbabwe', Journal of Constructive Theology 8(2), 59-69.

Togarasei, L., 2002b, 'Teaching Old Testament Studies in Zimbabwe's Theological Institutions in the HIV/AIDS Era', Zimbabwe Journal of Educational Research 14(13), 254-271.

Togarasei, L., 2008, 'Fighting HIV and AIDS with the Bible: Towards HIV and AIDS biblical criticism', in E. Chitando (ed.), Mainstreaming HIV in theology and religious studies: Experiences and explorations, pp. 71-82, WCC Publications, Geneva.

Togaraseil, L. 2009, Bible in Context: Essays Collection, University of Bamberg Press, Bamberg.

Togarasei, L. 2012, 'Pauline Challenge to African Masculinities: Reading Pauline texts in the context of HIV and AIDS', Acta Theologica Supplement 16, 148-160.

Udo, A.E., 1997, 'Women in God's World: Some biblical Affirmations', in E. Amoah (ed.), Where god reigns: Reflections on Women in God's World, pp. 20-25, Sam-Woode Ltd, Accra.

Ukpong, J.S., 2000, 'Developments in Biblical Interpretation in Africa: Historical and hermeneutical directions', in G.O. West \& M.W. Dube (eds.), The Bible in Africa: Transactions, trajectories and trends, pp. 11-28, Brill, Leiden.

Ukpong, J.S., 2002, 'Reading the Bible in a Global Village: Issues and Challenges from African Readings', in J.S. Ukpong et al (eds.), Reading the Bible in the Global Village: Cape Town, pp. 9-39, Society of Biblical Literature, Atlanta.

Umeagudosu, M.A., 1997, 'The Earth belongs to God: Biblical expositions through the eyes of a Nigerian woman', in E. Amoah (ed.), Where god reigns: Reflections on Women in God's World, pp. 15-25, Sam-Woode Ltd, Accra. 